\title{
High Concentrations of Monocarbamide Dihydrogensulfate Are Needed To Thin Nectarine Blooms in Israel
}

\author{
Joshua D. Klein \\ Agricultural Research Organization, The Volcani Center, Bet Dagan 50250, \\ Israel
}

Shlomo Cohen

Institute for Agricultural Research According to the Torah, D.N. Emeq Soreq 76812, Israel

Additional index words. WILTHIN, Prunus persica, flower

The use of monocarbamide dihydrogensulfate (WILTHIN), a $79 \%$ to $81 \%$ a.i. formulation (Unocal Corp., Los Angeles), for thinning fruit trees at bloom was recently described for apples (Malus domestica Borkh.) (Williams, 1993) and for peaches and nectarines [Prunus persica (L.) Batsch] (Myers et al., 1993). Satisfactory thinning was achieved with WILTHIN concentrations of $0.25 \%$ to $0.5 \%(\mathrm{v} / \mathrm{v})$. Both papers described results obtained in temperate zones of North America and Australasia. We evaluated the effect of WILTHIN on several nectarine cultivars in Israel, a subtropical area, and report here that WILTHIN thinned adequately only when sprayed at $3.0 \%(\mathrm{v} / \mathrm{v})$.

In preliminary experiments in Jan. and Feb. 1994, flowering 'Floridaglow' nectarine trees were sprayed to runoff with $0.25 \%$ to $4.0 \%$ WILTHIN. No thinning occurred at $0.25 \%$ to $1.0 \%$, although those are the application rates recommended by both Unocal Corp. and Myers et al. (1993). Application of 2\% WILTHIN resulted in flower thinning with very slight subsequent phytotoxicity to young leaves, while at $4 \%$ virtually all flowers were removed and there was significant subsequent leaf damage (data not shown). In the main experiment, the flowers $(\approx 500)$ on one major scaffold branch (7 to $12 \mathrm{~cm}$ in diameter) of

Received for publication 19 Oct. 1994. Accepted for publication 13 Mar. 1995. We thank Dan Ga' ash of the Dept. of Horticulture, Volcani Center-Agricultural Research Organization (ARO), for much helpful discussion; Y. Goldberg, S. Entman, D. Blau, P. Novick, D. Squire, and D. Darmon for their cooperation in the orchards; and Y. Fluksman of Efal Industries, Herzliya, Israel, for assistance in obtaining WILTHIN. Contribution from the ARO-Volcani Center, no. 1400-E, 1994 series. The cost of publishing this paper was defrayed in part by the payment of page charges. Under postal regulations, this paper therefore must be hereby marked advertisement solely to indicate this fact. each treated nectarine tree were counted at full bloom (29 Mar. to 7 Apr. 1994, depending on cultivar). Three replicate branches (trees) each were left unsprayed (controls), or were sprayed to wetness with $1.5 \%$ or $3 \%$ WILTHIN, using a 1.5-liter, high-pressure handsprayer or a 10liter backpack sprayer. Half a liter of spray material was usually adequate to cover a scaffold limb. Temperature at spraying averaged $21 \mathrm{C}$, while relative humidity averaged $60 \%$. Fruit set was determined 8 weeks after spraying.

The experiment was repeated in each of four ('Flavortop'), three ('Fantasia'), and two ('Fairlane') orchards. 'Early Sungrande' and 'Snow Queen' were treated in one orchard each. Orchards were located on the coastal plain of Israel, in the Jerusalem hills, and in the southern Hebron hills. The design was a randomized complete block, with trees as plots and orchard locations as replicate blocks.

Location did not affect final fruit set (data not shown). Final fruit set in 'Flavortop' and 'Fairlane' was reduced by application of 3\% WILTHIN, but the response of 'Fantasia' was nonsignificant, presumably because of the very low fruit set on control branches (Table 1). The final fruit set over all cultivars, including those sprayed only in one orchard, averaged $35 \%$, $28 \%$, and $17 \%\left(\mathrm{LSD}_{0.05}=6.9\right)$ for $0 \%, 1.5 \%$, and $3 \%$ WILTHIN, respectively. These results are in line with the desire of many stone fruit growers in Israel for a final fruit set of $\approx 20 \%$ of initial flowering, which usually translates to 800 fruit per tree. There was no damage to leaves or to fruit finish. Fruit seemed to be evenly distributed along most limbs, although there was a subjective impression that fewer fruit set on the thinnest branches.

During Winter 1993-94 in Israel, mean temperatures were 2 to $3 \mathrm{C}$ higher than usual, which resulted in insufficient accumulation of chilling units in many orchards. As a result, fruit set was frequently far below the average of $60 \%$ to $80 \%$ of full bloom (D. Ga'ash, personal communication). Despite the low fruit set, spraying with WILTHIN did not result in excessive thinning. Fruit set after application of 3\% WILTHIN was reduced by $46 \%$ compared to controls, which is similar to the 55\% reduction described by Myers et al. (1993) after applying $0.5 \%$ to $1.0 \%$ WILTHIN.

Our data support the overall conclusions of Myers et al. (1993) that WILTHIN is an effective flower-thinning agent for stone fruit. However, we only obtained satisfactory results at much higher concentrations than those recommended by the manufacturer or by Myers et al. (1993). The application rates of agrichemicals in Israel frequently must be increased over the rates recommended in more temperate areas. For example, napthalenacetic acid for thinning is applied to apple trees at up to $15 \mathrm{ppm}$ in North America (Williams, 1979), while the recommended rate in Israel is up to $40 \mathrm{ppm}$ (Ben-Arie, 1992). The potential necessity of using higher rates of WILTHIN to obtain satisfactory results should not be ignored by growers and researchers in semitropical or tropical areas.

\section{Literature Cited}

Ben-Arie, Z. (ed.). 1992. Spray recommendations for deciduous orchards (in Hebrew). Israel Ministry of Agr. Pamphlet.

Myers, S.C., A. King, and A.T. Savelle. 1993. Bloom thinning of 'Winblo' peach and 'Fantasia' nectarine with monocarbamide dihydrogensulfate. HortScience 28:616-617.

Williams, M.W. 1979. Chemical thinning of apples. Hort. Rev. 1:270-300

Williams, M.W. 1993. Sulfcarbamide, a blossomthinning agent for apples. HortTechnology 3:322-324.

Table 1. Influence of monocarbamide dihydrogensulfate (WILTHIN) concentration on final fruit set in 'Flavortop', 'Fantasia', and 'Fairlane' nectarine cultivars.

\begin{tabular}{lllrr}
\hline \hline & \multicolumn{4}{c}{ Final fruit set $(\%)^{\mathrm{z}}$} \\
\cline { 2 - 5 } Cultivar $^{\mathrm{y}}$ & \multicolumn{4}{c}{ WILTHIN concn (\%) } \\
\cline { 2 - 5 } & $0^{\mathrm{x}}$ & 1.5 & 3.0 & LSD $_{0.05}$ \\
\hline Flavortop & 41 & 30 & 17 & 11.2 \\
Fantasia & 28 & 18 & 23 & 9.3 \\
Fairlane & 44 & 41 & 17 & 11.5
\end{tabular}

${ }^{2}$ Number of fruitlets set after fruit drop, relative to number of flowers at full bloom.

'Number of trees per treatment: 'Flavortop', 12; 'Fantasia', 9; 'Fairlane', 6.

${ }^{x}$ Unsprayed controls. 